\title{
Promoting Electrocatalytic Conversion of Polysulfide by Cobalt Disulfide Nanocrystals for Lithium Sulfur Batteries
}

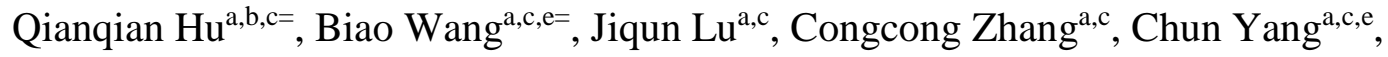
Shiyong Chang ${ }^{\mathrm{b}}$, Haiyong Dong ${ }^{\mathrm{b}}$, Chunyu Wu ${ }^{\mathrm{b}}$, Ye Hong ${ }^{\mathrm{d}^{*}}$, Lingzhi Zhang ${ }^{\mathrm{a}^{*}}$

a. Guangzhou Institute of Energy Conversion, Chinese Academy of Sciences; CAS Key Laboratory of Renewable Energy; Guangdong Provincial Key Laboratory of New and Renewable Energy Research and Development, Guangzhou, Guangdong, 510640, China

b. GAC Automotive Research \& Development Center, Guangzhou, 511434, China.

c. University of Chinese Academy of Sciences, Beijing, 100049, China

d. Industrial Training Center, Guangdong Polytechnic Normal University, 510665, China

e. Nano Science and Technology Institute, University of Science and Technology of China, Suzhou 215123, China

*Corresponding author: Tel.: +86 2037246025; fax: +86 2037246026.

E-mail addresses: 1zzhang@ms.giec.ac.cn hongye2016@163.com

Qianqian Hu and Biao Wang contributed equally to this work. 


\section{Table of Contents}

Figure S1. SEM images of GO (a and b); $\mathrm{rGO}\left(\mathrm{c}\right.$ and d); $\mathrm{CoS}_{2}$ (e and f). S3

Figure S2. Raman (a) spectra of $\mathrm{rGO} / \mathrm{CoS}_{2}, \mathrm{rGO}$, and FTIR (b) spectra of $\mathrm{rGO} / \mathrm{CoS}_{2}$, $\mathrm{rGO}, \mathrm{CoS}_{2}$.

Figure S3. TGA curves of $\mathrm{rGO} / \mathrm{CoS}_{2}$ in air.

S4

Figure S4. (a) The cycling performance of $\mathrm{rGO} / \mathrm{CoS}_{2} / \mathrm{S}, \mathrm{rGO} / \mathrm{S}, \mathrm{CoS}_{2} / \mathrm{S}$; (b) the corresponding galvanostatic discharge and charge curves for $\mathrm{rGO} / \mathrm{CoS}_{2} / \mathrm{S}, \mathrm{rGO} / \mathrm{S}$, $\mathrm{CoS}_{2} / \mathrm{S}$ at $2 \mathrm{C}$.

Figure S5. (a) The cycling performance and the areal capacity curves of $\mathrm{rGO} / \mathrm{CoS}_{2} / \mathrm{S}$ at $0.5 \mathrm{C}$ after $0.05 \mathrm{C}$ activation with a sulfur loading of $4.5 \mathrm{mg} / \mathrm{cm}^{2}$; (b) the corresponding galvanostatic discharge and charge curves for $\mathrm{rGO} / \mathrm{CoS}_{2} / \mathrm{S}$ at $0.05 \mathrm{C}$ and $0.5 \mathrm{C}$.

Figure S6. The SEM images with EDX for lithium metal surface after 200 cycles at $0.5 \mathrm{C}$ for $\mathrm{rGO} / \mathrm{CoS}_{2} / \mathrm{S}, \mathrm{rGO} / \mathrm{S}$, and $\mathrm{CoS}_{2} / \mathrm{S}$ cells, respectively. .S5

Table S1. The corresponding deposited sulfur content on lithium metal surface after 200 cycles at $0.5 \mathrm{C}$ for $\mathrm{rGO} / \mathrm{CoS}_{2} / \mathrm{S}, \mathrm{rGO} / \mathrm{S}$, and $\mathrm{CoS}_{2} / \mathrm{S}$ cells, respectively. .S6

Figure S7. (a) CV curves at $2 \mathrm{mV} / \mathrm{s}$ of the symmetric cells with and without $\mathrm{Li}_{2} \mathrm{~S}_{6}$ for $\mathrm{CoS}_{2}$; (b) the CV comparison for all the cells at $0.2 \mathrm{mV} / \mathrm{s}$; (c) Tafel slopes for the electrodes from peak a of the CV curves.

S6

Figure S8. The SEM images for the cathode electrodes (rGO, commercial $\mathrm{CoS}_{2}$ ) of the symmetric cells before and after scanning from $0 \mathrm{~V}$ to $0.8 \mathrm{~V}$.

Figure S9. Elemental mapping of C, Co, S with EDX (inset figure) for rGO based cathode from disassembled symmetric cells after scanning from $0 \mathrm{~V}$ to $0.8 \mathrm{~V}$. S8

Figure S10. EDX (inset figure) for $\mathrm{CoS}_{2}$ based cathode from disassembled symmetric cells after scanning from $0 \mathrm{~V}$ to $0.8 \mathrm{~V}$.

Table S2. The content of deposited sulfur on the cathode surface after scanning from $0 \mathrm{~V}$ to $0.8 \mathrm{~V}$ at $0.2 \mathrm{mV} / \mathrm{s}$ for $\mathrm{rGO} / \mathrm{CoS}_{2}, \mathrm{rGO}$, and $\mathrm{CoS}_{2}$ symmetric cells. S9 

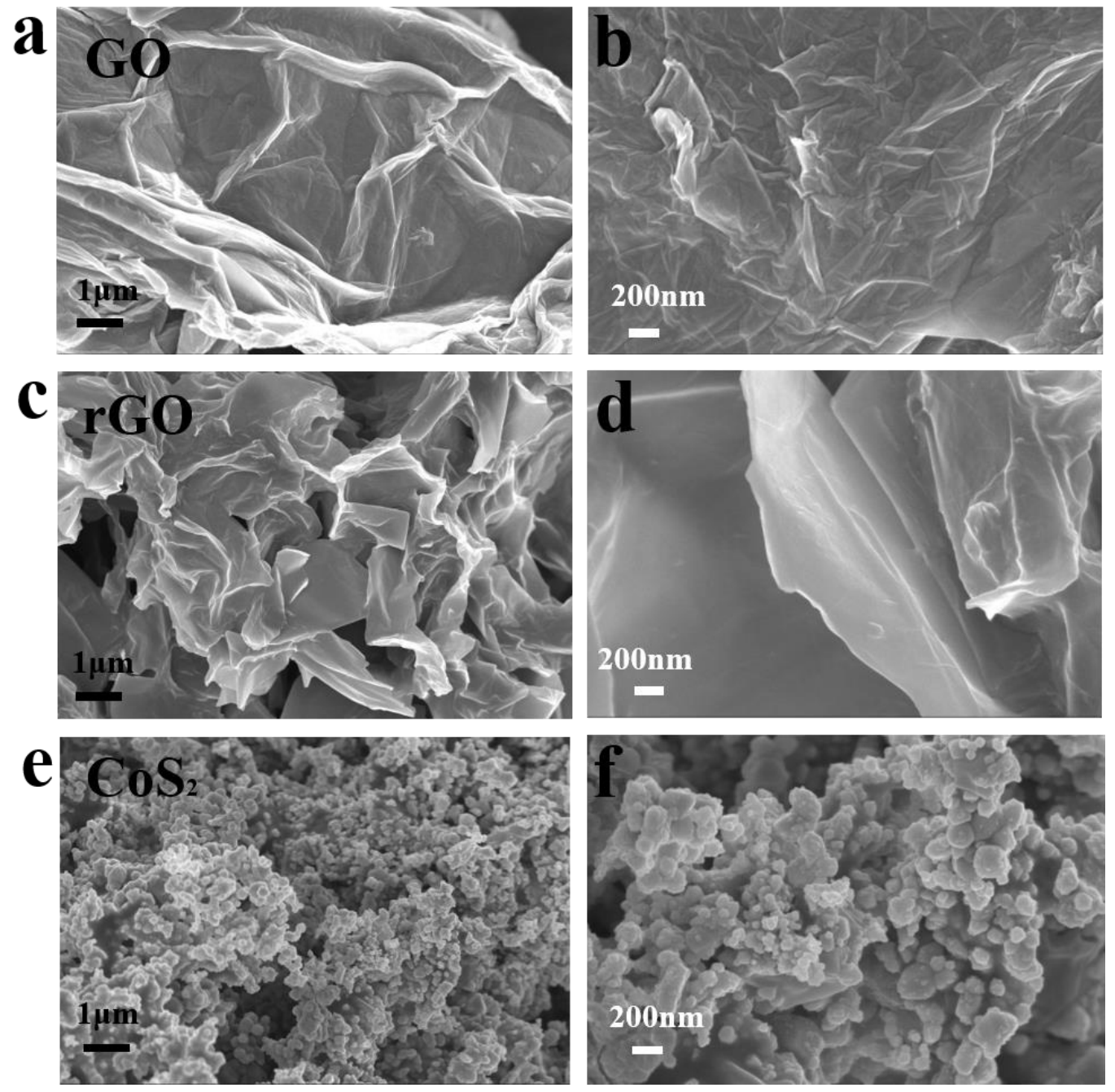

Figure S1. SEM images of GO (a and b); $\mathrm{rGO}\left(\mathrm{c}\right.$ and d); $\mathrm{CoS}_{2}$ (e and f).
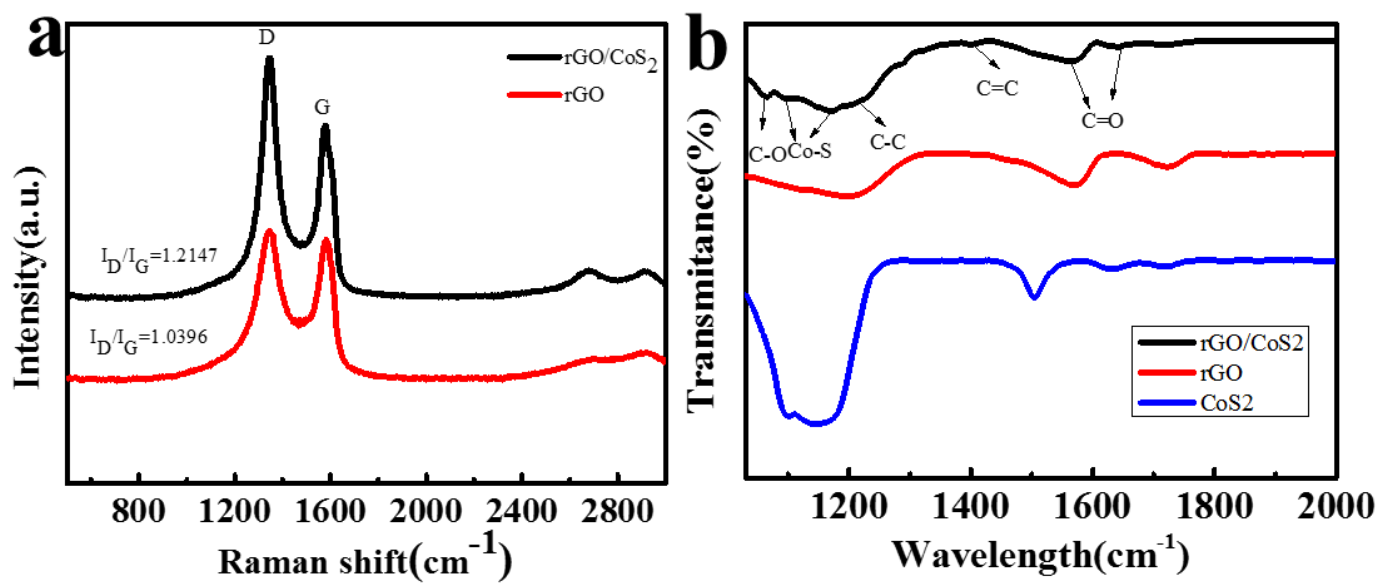

Figure S2. Raman (a) spectra of $\mathrm{rGO} / \mathrm{CoS}_{2}, \mathrm{rGO}$, and FTIR (b) spectra of $\mathrm{rGO} / \mathrm{CoS}_{2}$, $\mathrm{rGO}, \mathrm{CoS}_{2}$. 


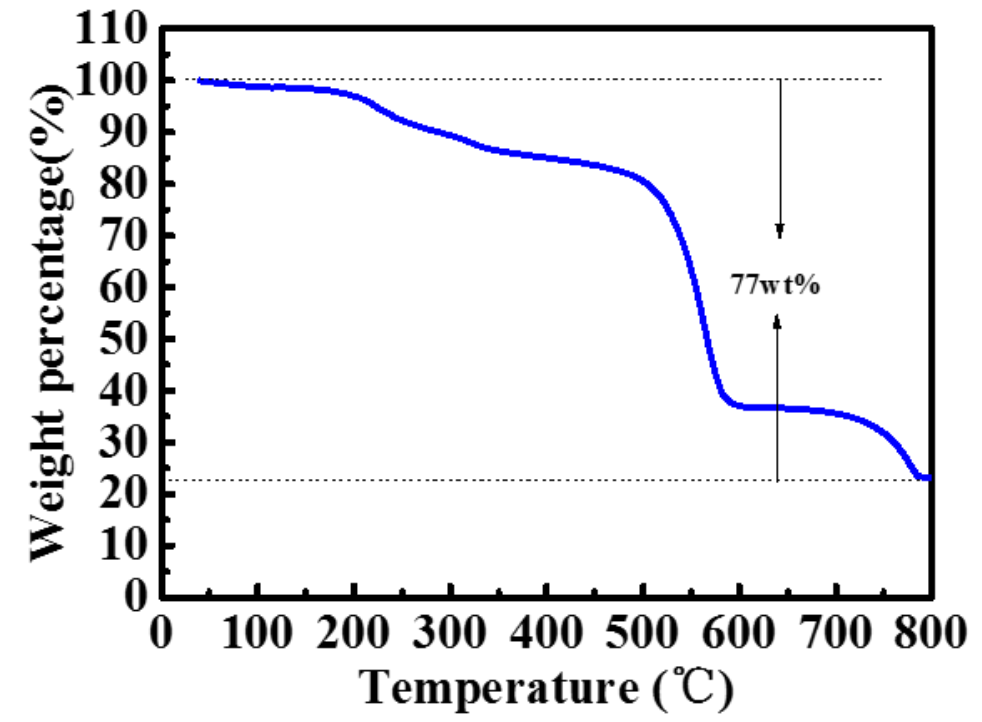

Figure S3. TGA curves of $\mathrm{rGO} / \mathrm{CoS}_{2}$ in air.
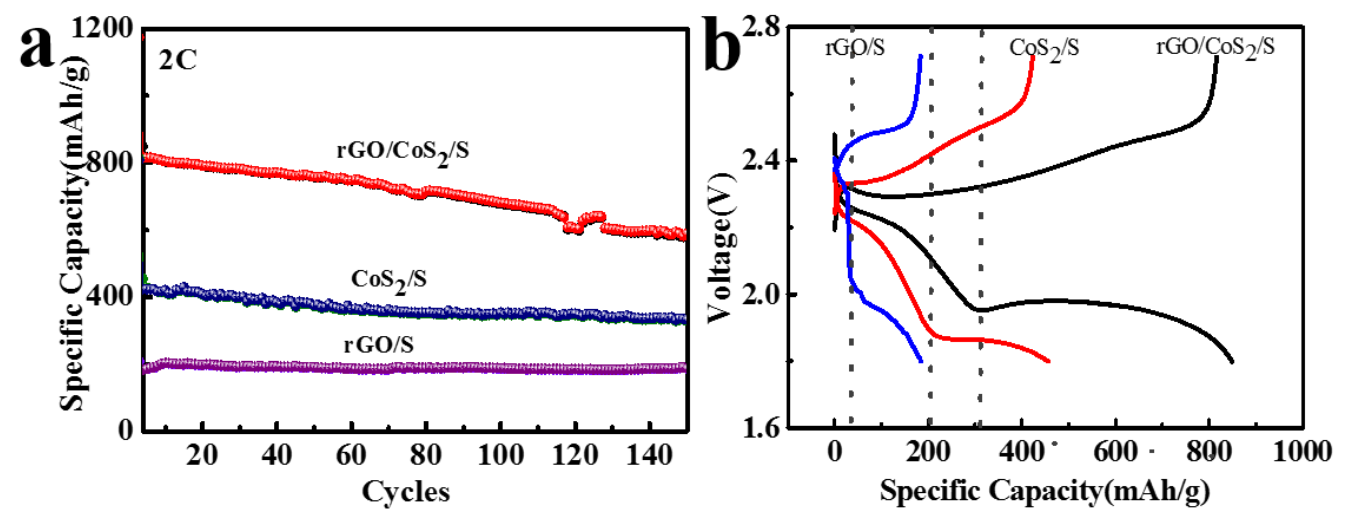

Figure S4. (a) The cycling performance of $\mathrm{rGO} / \mathrm{CoS}_{2} / \mathrm{S}, \mathrm{rGO} / \mathrm{S}, \mathrm{CoS}_{2} / \mathrm{S}$; (b) the corresponding galvanostatic discharge and charge curves for $\mathrm{rGO} / \mathrm{CoS}_{2} / \mathrm{S}, \mathrm{rGO} / \mathrm{S}$, $\mathrm{CoS}_{2} / \mathrm{S}$ at $2 \mathrm{C}$. 

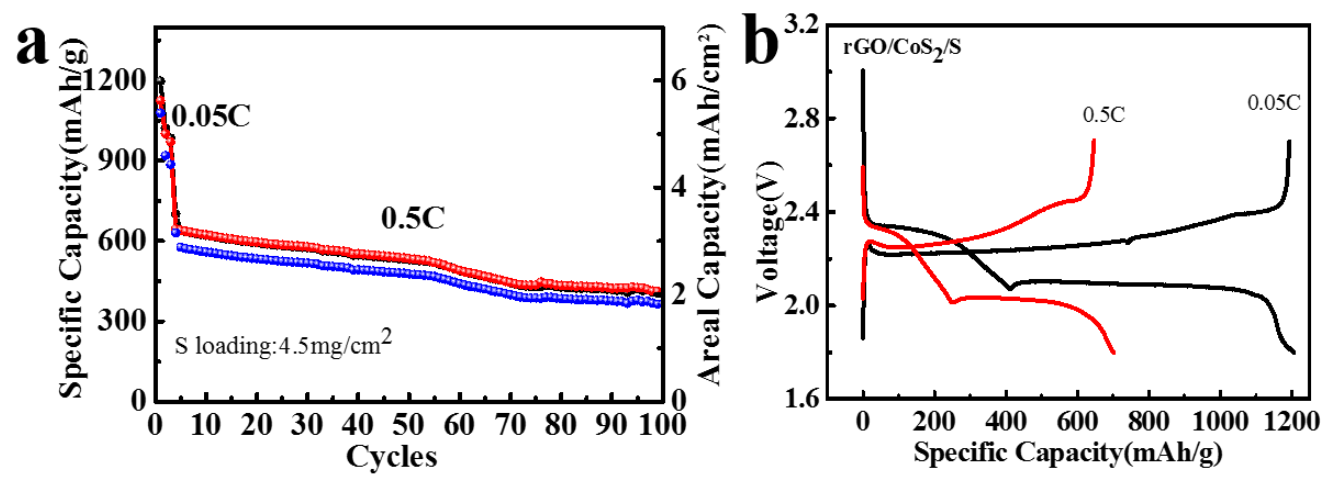

Figure S5. (a) The cycling performance and the areal capacity curves of $\mathrm{rGO} / \mathrm{CoS}_{2} / \mathrm{S}$ at $0.5 \mathrm{C}$ after $0.05 \mathrm{C}$ activation with a sulfur loading of $4.5 \mathrm{mg} / \mathrm{cm}^{2}$; (b) the corresponding galvanostatic discharge and charge curves for $\mathrm{rGO} / \mathrm{CoS}_{2} / \mathrm{S}$ at $0.05 \mathrm{C}$ and $0.5 \mathrm{C}$.

rGO/CoS $2 / S$
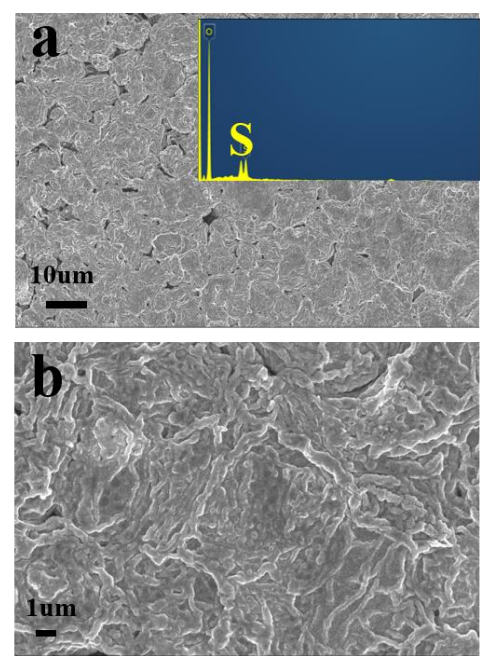

rGO/S
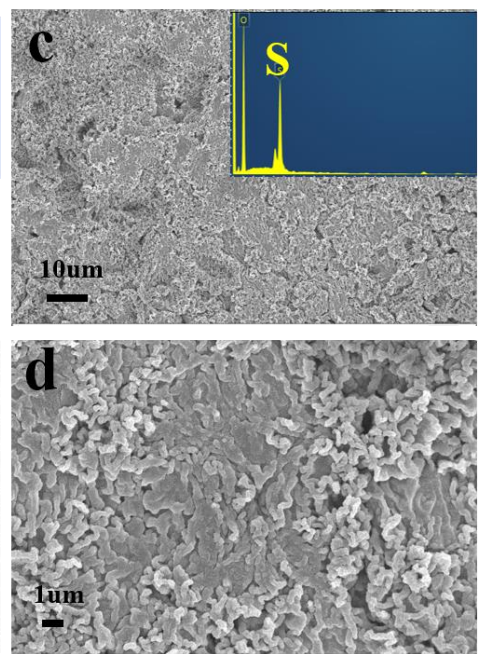

$\mathrm{CoS}_{2} / \mathrm{S}$
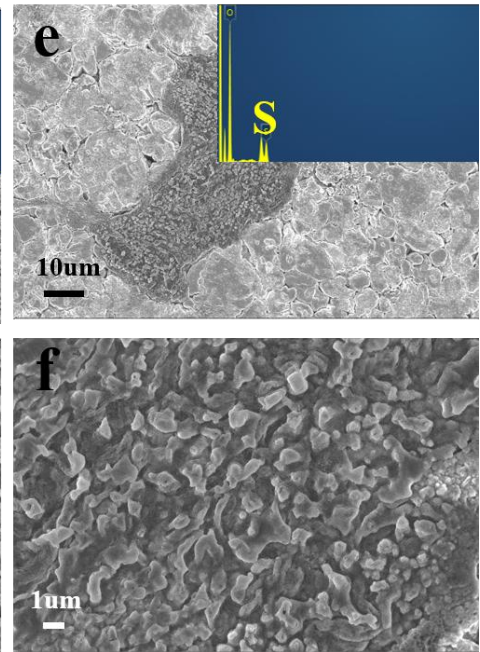

Figure S6. The SEM images with EDX for lithium metal surface after 200 cycles at $0.5 \mathrm{C}$ for $\mathrm{rGO} / \mathrm{CoS}_{2} / \mathrm{S}, \mathrm{rGO} / \mathrm{S}$, and $\mathrm{CoS}_{2} / \mathrm{S}$ cells, respectively. 


\begin{tabular}{|c|c|c|c|}
\hline Materials & $\mathrm{rGO} / \mathrm{CoS}_{2} / \mathrm{S}$ & $\mathrm{rGO} / \mathrm{S}$ & $\mathrm{CoS}_{2} / \mathrm{S}$ \\
\hline Deposited S (wt\%) & 10.73 & 24.6 & 11.21 \\
\hline
\end{tabular}

Table S1. The corresponding deposited sulfur content on lithium metal surface after 200 cycles at $0.5 \mathrm{C}$ for $\mathrm{rGO} / \mathrm{CoS}_{2} / \mathrm{S}, \mathrm{rGO} / \mathrm{S}$, and $\mathrm{CoS}_{2} / \mathrm{S}$ cells, respectively.
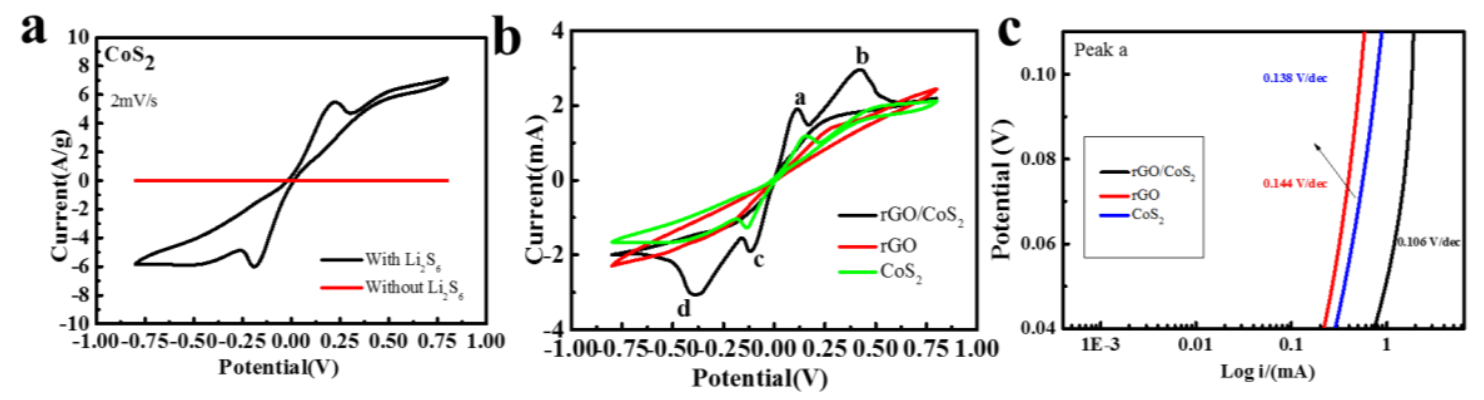

Figure S7. (a) CV curves at $2 \mathrm{mV} / \mathrm{s}$ of the symmetric cells with and without $\mathrm{Li}_{2} \mathrm{~S}_{6}$ for $\mathrm{CoS}_{2}$; (b) the CV comparison for all the cells at $0.2 \mathrm{mV} / \mathrm{s}$; (c) Tafel slopes for the electrodes from peak a of the CV curves. 

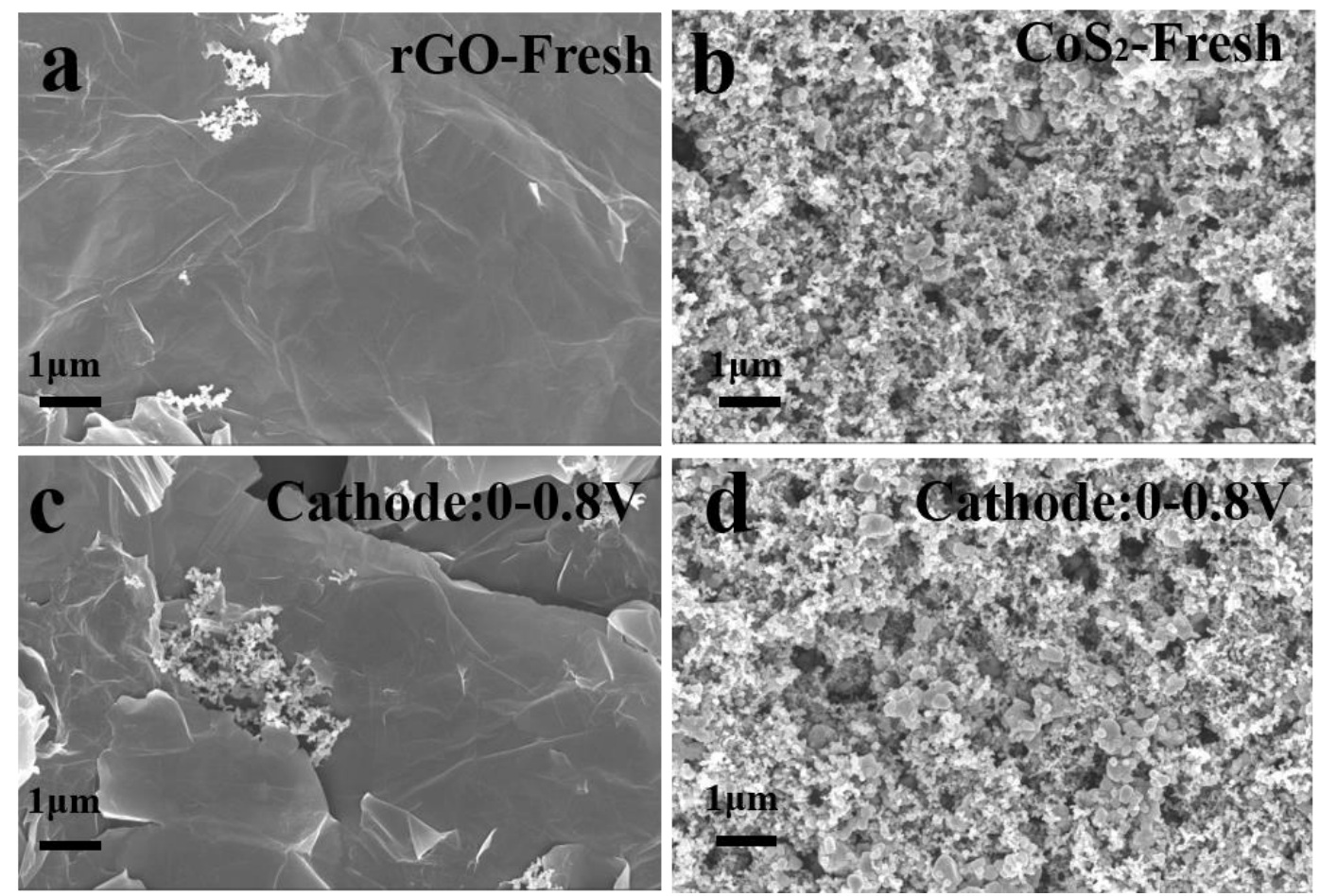

Figure S8. The SEM images for the cathode electrodes (rGO, commercial $\mathrm{CoS}_{2}$ ) of the symmetric cells before and after scanning from $0 \mathrm{~V}$ to $0.8 \mathrm{~V}$. 


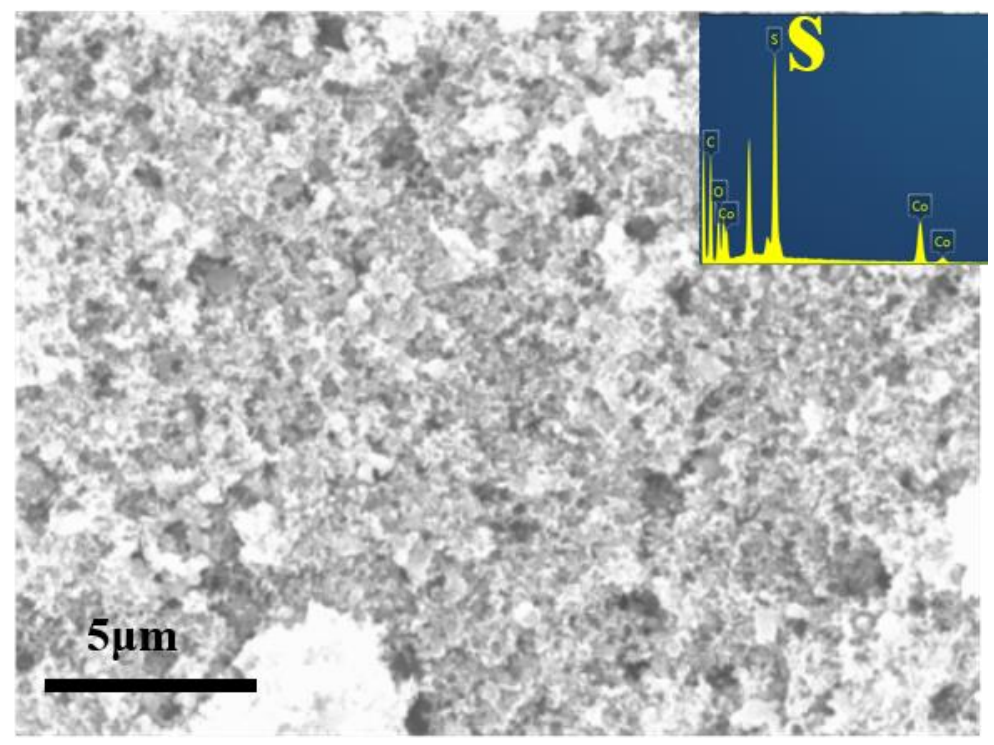

Figure S9. Elemental mapping of $\mathrm{C}, \mathrm{Co}, \mathrm{S}$ with $\mathrm{EDX}$ (inset figure) for rGO based cathode from disassembled symmetric cells after scanning from $0 \mathrm{~V}$ to $0.8 \mathrm{~V}$.
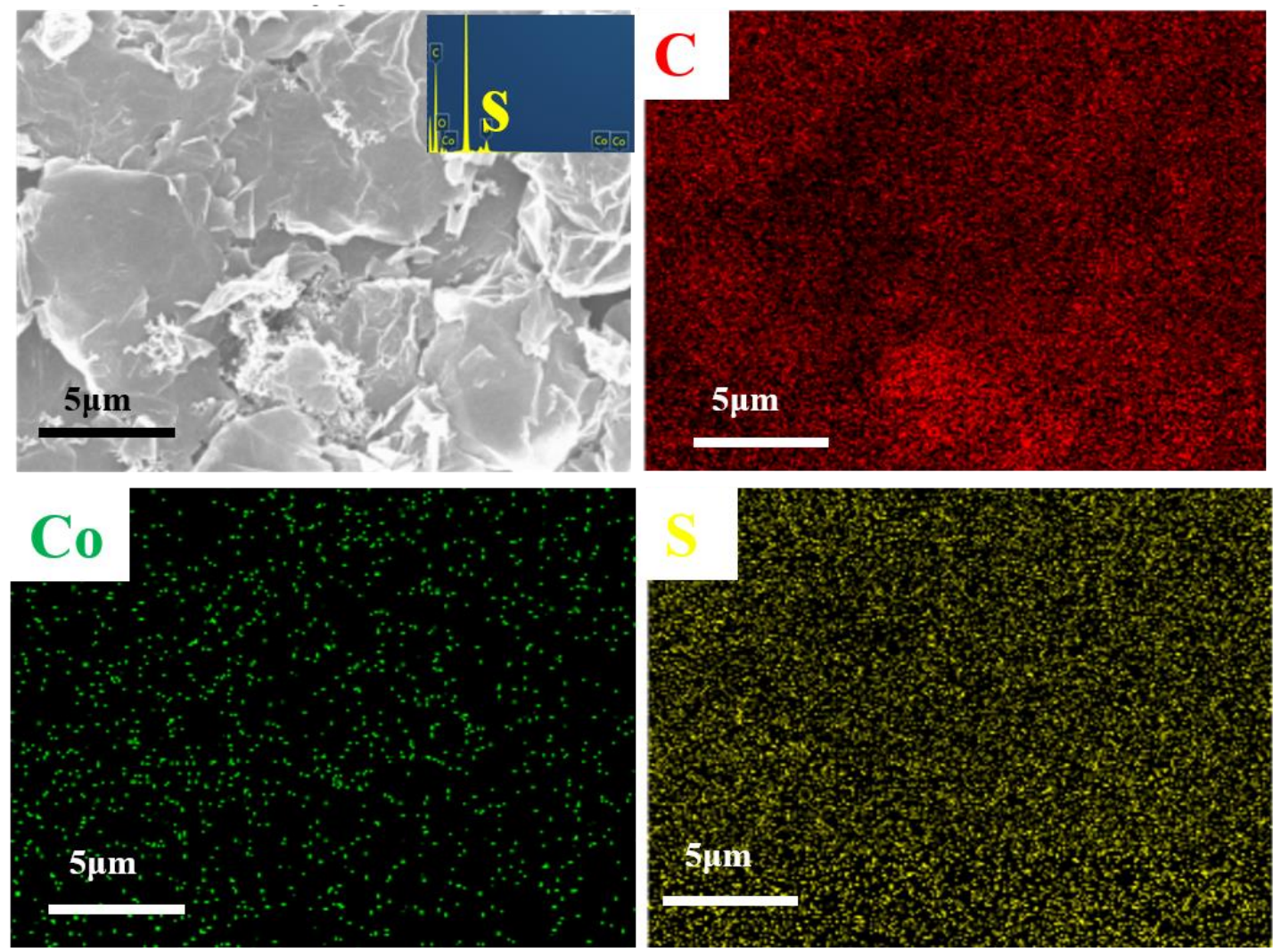

Figure S10. EDX (inset figure) for $\mathrm{CoS}_{2}$ based cathode from disassembled symmetric cells after scanning from $0 \mathrm{~V}$ to $0.8 \mathrm{~V}$. 


\begin{tabular}{|c|c|c|c|}
\hline $\begin{array}{c}\text { Wt } \% \\
\text { Materials }\end{array}$ & $\mathrm{rGO} / \mathrm{CoS}_{2} / \mathrm{S}$ & $\mathrm{rGO}$ & $\mathrm{CoS}_{2}$ \\
\hline $\mathrm{O}$ & 7.45 & 20.23 & 16.64 \\
\hline $\mathrm{S}$ & 23.29 & 3.18 & 13.09 \\
\hline Co & 5.32 & 0 & 14.69 \\
\hline Deposited $\mathrm{S}$ & 20.52 & 3.18 & 5.5 \\
\hline
\end{tabular}

Table S2. The content of deposited sulfur on the cathode surface after scanning from $0 \mathrm{~V}$ to $0.8 \mathrm{~V}$ at $0.2 \mathrm{mV} / \mathrm{s}$ for $\mathrm{rGO} / \mathrm{CoS}_{2}, \mathrm{rGO}$, and $\mathrm{CoS}_{2}$ symmetric cells.

For the electrode disassembled from the symmetric cell, the $\mathrm{S}$ is from the deposited $\mathrm{S}$ by polysulfide conversion and the primary cobalt disulfide. In this table, the weight percentage of Co is known, then the weight percentage of $S$ is obtained based on the molar mass of $\mathrm{Co}, \mathrm{S}$. Then the deposited $\mathrm{S}$ is calculated by the whole mass percentage of $\mathrm{S}$ minus the weight percentage of $\mathrm{S}$ in $\mathrm{CoS}_{2}$. 